SPORT GYMNASTICS 1 (2) (2020)

SPORT GYMNASTICS : Jurnal Ilmiah Pendidikan Jasmani

https://ejournal.unib.ac.id/index.php/gymnastics/index

\title{
PERKEMBANGAN EKSTRAKURIKULER PENCAK SILAT SISWA SMA NEGERI KABUPATEN LEBONG
}

Pitri Rahmadani ${ }^{1}$, Dian Pujianto ${ }^{2}$, Santun Sihombing ${ }^{3}$

${ }^{123}$ Prodi Penjas, FKIP, Universitas Bengkulu, Kota Bengkulu, Indonesia

\begin{tabular}{l}
\hline Info Artikel \\
\hline Sejarah Artikel: \\
Diterima Oktober 2020 \\
Direvisi Oktober 2020 \\
Diterima Oktober 2020 \\
Tersedia online Oktober 2020 \\
\hline \\
Kata kunci: \\
LKPD, Penguatan Pendidikan \\
Karakter, PJOK \\
\hline
\end{tabular}

\begin{abstract}
Abstrak
Penelitian ini bertujuan untuk mengetahui bagaimana perkembangan ekstrakurikuler pencak silat SMA Negeri Kabupaten Lebong dan faktor-faktor yang mempengaruhi prestasi siswa. Jenis penelitian ini deskriptif kualitatif. Subjek penelitian adalah 64 atlet ekstrakurikuler pencak silat SMA Negeri di Kabupaten Lebong, kemudian pengambilan data penelitian dengan teknik kuesioner dan wawancara. Analisis data yang digunakan penelitian adalah reduksi data, display, dan conclucing drawing. Hasil presentase penelitian ini diperoleh bahwa sumber daya manusia ekstrakurikuler pencak silat SMA Negeri Kabupaten Lebong 27\% kategori kurang, sarana prasarana $24 \%$ kategori kurang, pengelolaan pendanaan $33 \%$ kategori kurang, metode dan program latihan $23 \%$ kategori kurang. Dengan demikian dapat disimpulkan bahwa perkembangan ekstrakurikuler pencak silat SMA Negeri Kabupaten Lebong termasuk kategori kurang..
\end{abstract}

\begin{abstract}
The studyaims to find out how the development of pencak silat extracuricular activities at Lebong Regency High School and the factor that influencer student achievemrnt. This type of research is descriptive qualitative. The research subjects were 64 high school pencak silat extracurricular athletes in Lebong Regency, then collecting research data using questionnaire and interview techniques. Analysis of the data used in this research is data reduction, display, and conclucing drawing. The results of this study showed that the pencak silat extracurricular human resousrces in Lebong Regency were $27 \%$ in the poor category, 24\% in the poor infrastructure, $33 \%$ in the funding management, in the training method and program $23 \%$ in the inadequate category. Thus it can be concluded that the development of pencak silat extracurricular activities in the Lebong Regency High School is in the inadequate category.
\end{abstract}

Alamat yang sesuai: Jl. Embog Panjang Kota Lebong

Email yang sesuai: pitrirahmadani2017@gmail.com
ISSN 2746-055X (online)

DOI : 10.33369/gymnastics.v1i2.12861 


\section{PENDAHULUAN}

Olahraga adalah suatu hal yang umum dan sering dilakukan sehari-hari. Aktivitas fisik ini bahkan kerap kali dikaitkan dengan kesehatan. Tak hanya berguna untuk kesehatan fisik, olahraga juga dapat meningkatkan kualitas hidup seseorang secara keseluruhan. Segala bentuk aktifitas fisik baik jasmani maupun rohani yang dilakukan dengan maksud untuk kesehatan dan untuk memperkuatkan otot-otot tubuh. Kegiatan ini dalam perkembangannya dapat di lakukan sebagai kegiatan menyenangkan,menghibur, dan prestasi. Kementrian Negara Pemuda dan Olahraga Republik Indonesian. " Olahraga prestasi dimaksud sebagai upaya untuk meningkatkan kemampuan dan potensi olahragawan dalam rangka meningkatkan harkat dan martabat bangsa.

Indonesia adalah Negara yang kaya akan seni dan budaya mulai dari tari, adat istiadat, beladiri pencak silat dan lainnya. Hampir di semua wilayah pasti memiliki ragam seni, ragam budaya, dan ciri khas masing-masing yang sekaligus sebagai penggambar yang wilayah itu sendiri. Pencak silat merupakan budaya dan seni bela diri warisan bangsa yang mempunyai nilai luhur. Dalam perkembangan pencak silat ini cenderung mengarah pada olahraga prestasi yang memiliki kompetisi, Menurut Kriswanto (2015: 117) kategori pertandingan pencak silat terdiri dari antara lain: 1) kategori tanding, 2) kategori tunggal, 3) kategori ganda, dan 4) kategori regu. Kategori tanding adalah kategori pertandingan yang menampilkan dua orang pesilat dari kontingen yang berbeda-beda dan berhadapan dengan menggunakan unsur pembelaan dan serangan, menangkis, mengelak, menghindar, menyerang pada sasaran dan menjatuhkan lawan dengan menggunakan taktik dan teknik bertanding, ketahanan, stamina dan semangat juang dengan menggunakan pola langkah yang manfaatnya kekayaan teknik jurus untuk mendapatkan nilai terbanyak. Adapun kategori tunggal yaitu kategori pertandingan pencak silat yang menampilkan seorang pesilat memperagakan kemahirannya, dalam jurus tunggal baku secara benar, tepat, mantap, penuh penjiwaan, baik dengan tangan kosong dan bersenjata serta tunduk terhadap peraturan dan ketentuan yang berlaku.

Kategori ganda merupakan kategori pertandingan pencak silat yang menampilkan dua orang pesilat dari kontingen yang sama, memperagakan kemahiran dan kekayaan teknik jurus serang bela pencak silat yang dimiliki. Gerakan serang bela ditampilkan secara terencana, efektif, estetis, logis, mantap dalam jumlah rangkaian seri yang teratur baik bertenaga dan cepat mampun gerakan lembut penuh penjiwaan dengan tangan kosong dan dilanjutkan dengan bersenjata dalam waktu 3 menit serta tunduk terhadap peraturan yang berlaku. Adapun kategori regu adalah kategori pertandingan pencak silat yang menampilkan tiga orang pesilat dari kontingen yang sama memperagakan kemahirannya dalam jurus regu baku secara benar, tepat mantap, penuh penjiwaan dan kelompok dengan tangan kosong serta tunduk terhadap peraturan dan ketentuan yang berlaku. 
Awalnya prestasi pencak silat Indonesia merupakan acuan bagi negarabegara Asia Tenggara. Namun dulu prestasi pencak silat Indonesia cendrung mengalami fluktuatif, khusunya pada kategori tanding. Artinya, pencak silat Indonesia belum konsisten dalam pencapaian prestasi pada setiap pertandingan yang diikuti. Hal ini tentunya menjadi tantangan bagi bangsa indonesia untuk kembali meningkatkan prestasi gerak pencak silat khusunya di kawasan Asia Tenggara dan Dunia pada umumnya. Pada seperti yang kita lihat sekarang ini alhamdulilah olahraga pencak silat sudah maju dan berkembang,baik itu di Asia maupun di Dunia. Sekarang ini banyak atlet yang sudah mewakili Indonesia di tingkat dunia, khusunya pada cabang olahraga pencak silat.

Tingkat Sekolah Menengah Atas Pertama (SMA N) beberapa sekolah sudah ada ekstrrakurikuler pencak silat melalui muatan kurikulum baik secara instrakurikuler maupun ektrakurikuler. Ekstrakurikuler pencak silat harus mendapatkan perhatian, baik unsur pimpinan sekolah, guru olahraga pembina ekstrakurukuler, serta orang tua siswa, apabila semua unsur-unsur terkait tersebut dapat terlibat dalam pembinaan olahraga pencak silat diharapkannya perkembangan akan lebih baik. Pada Kabupaten Lebong sendiri terdapat 5 SMA Negeri, Tapi saya memilih 4 SMA Negeri di Kabupatem Lebong. dari 5 SMA Negeri tidak semua SMA Negeri mengadakan kegiatan ekstrakurikuler Pencak Silat, adapun beberapa faktor yang membuat kegiatan ekstrakurikuler ini tidak diadakan, penyebabnya tidak ada dukungan dari pihak sekolah, kemudian sarana dan prasarana yang terbatas. Berdasarkan survey awal penulis tentang sekolah- sekolah yang melakukan kegiatan ekstrakurikuler pencak silat, ternyata dari 5 SMA Negeri yang ada di kabupaten Lebong hanya 3 SMA Negeri yang masih aktif dalam kegiatan ekstrakurikuler Pencak Silat, diantaranya, SMA N 01 Lebong, SMA N 05 Lebong, SMA N 03 Lebong. Sengakan yang pasif nya SMA Negeri 04 Lebong dan SMA Negeri 02 Lebong. Informasi tentang pelaksanaan ekstrakurikuler Pencak Silat dari beberapa sekolah terdapat kendala dan faktor- faktor yang membuat kegiatan ekstrakurikuler

Pencak Silat tidak maju atau berkembang dan berjalan dengan baik, diantaranya kurang peran pihak sekolah untuk olahraga Pencak Silat, kemudian sarana prasana yang terbatas, ditambah lagi masih banyak pelatih yang belum mempunyai sertifikat pelatih, prestasi pencak silat semakin menurun dan belum adanya anggaran perdanaan untuk kegiatan ekstrakurikuler. Namun demikian ada juga beberapa sekolah yang telah berprestasi bahkan mempunyai atletatlet dengan kualitas yang baik dalam kompetisi- kompetisi ditingkat sekolah.

Dari uraian latar belakang yang telah dijelaskan maka penting dilakukannya penelitian yang berjudul : 'Perkembangan Ekstrakurikuler Pencak Silat Siswa SMA Negeri di Kabupaten Lebong'.

\section{METODE}

Sesuai dengan permasalahan dan tujuan penelitian yang telah diuraikan sebelumnya, bahwa penelitian yang dimaksud adalah tentang perkembangan ekstrakurikuler pencak silat siswa SMA Negeri di Kabupaten Lebong. Lima sekolah Negeri tercatat sebagai tempat penelitian peneliti. Jenis penelitian ini adalah penelitian lapangan yang bersifat deskriptif kualitatif. Peneliti menggunakan penelitian deskriptif 
dengan tujuan untuk mengungkapkan atau menyelidiki suatu keadaan yang sebenarnya. Deskriptif merupakan menggambarkan situasi yang sebenarnya yang sedang berlangsung. Metode yang digunakan yaitu metode survey adalah pengumpulan data dilapangan.Sugiyono (2012: 6) menyatakan bahwa metode survey yang digunakan untuk mendapatkan data dari tempat tertentu yang alamiah (bukan buatan), tetapi peneliti melakukan perlakuan dalam pengumpulan data, misalnya dengan mengedarkan kuesioner, tes, wawncara, instruktur dan sebagainya. Berdasarkan penjelasan peneliti akan mengambil data lapangan. Pada penelitian ini subjek penilitian adalah atlet 64 , pembina 4 dan pelatih 4 .dalam penelitian ini, peneliti menyediakan satu angket dengan menggunakan angket skala liker. Kemudian indikator tersebut dijadikan sebagai titik tolak untuk menyusun itemitem instrument yang dapat berupa pertanyaan. Jawaban dalam skala skala likert terdapat lima alternatif yaitu (5) sangat setuju; (4) satuju; (3) sedang; (2)sangat kurang; (1) sangat kurang. Dalam sakala liker perhitungan nilainya menggunakan rumus $\mathrm{P}=\mathrm{f} / \mathrm{n} \times 100 \%$ yang mana $\mathrm{P}$ adalah persentase, $\mathrm{f}$ adalah frekuensi jawaban seluruh responden, $\mathrm{n}$ adalah nilai ideal dan $100 \%$ adalah merupakan bilangan tetap. Sementara itu untuk mencari nilai ideal (n) menggunakan rumus $\mathrm{n}=$ nilai jawaban $\mathrm{x}$ jumlah responden (Arikunton, 2006: 246).

Teknik analisis data adalah suatu hal yang sangat penting dalam penelitian karena analisis data dapat memberi arti makna yang berguna dalam memecahkan masalah penelitian. Menurut Sugiyono dalam kalil buyung (2016: 40) mengemukakan bahwa setiap dalam penelitian kualitatif dilakukan sebelum memasuki lapangan, selama di lapangan dan setelah selesai di lapangan. Nasution dalam Sugiyono (2012: 245) menyatakan bahwa "Analisis data sebelum terjun ke lapangan, analisis di lakukan terhadap data hasil studi pendahuluan atau data sekunder, yang digunakan untuk fokus penelitian.

\begin{tabular}{ccc}
\multicolumn{3}{c}{ Tabel 1. Norma Pengkategorian } \\
\hline No & Rentang & Kategori \\
& Nilai & \\
\hline 1 & $81 \%-$ & Sangat Baik \\
& $100 \%$ & \\
\hline 2 & $61 \%-$ & Baik \\
& $80 \%$ & \\
\hline 3 & $41-60 \%$ & Cukup \\
\hline 4 & $21-40 \%$ & Kurang \\
\hline 5 & $0 \%-$ & Sangat Kurang \\
& $20 \%$ & \\
\hline
\end{tabular}

\section{HASIL DAN PEMBAHASAN}

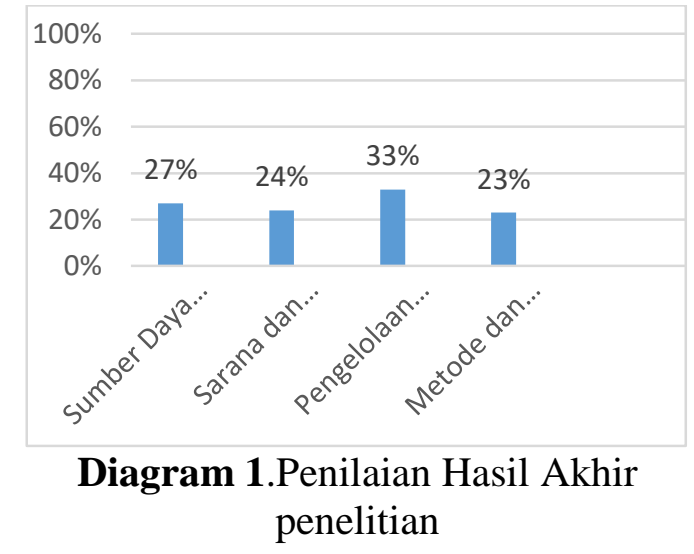

Dari hasil rata-rata keseluruhan diatas simber daya manusia eksrakurikuer pencak silat SMA Neheri Kabupaten Lebong kategori kurang dengan persentase 23\%, sarana dan Prasarana kategori kurang dengan persentase 24\% , Pengelolaan pendanaan kategori kurang dengan persentase $33 \%$ dan metode program latihan kategori kurang dengan persentase $23 \%$. 


\section{PEMBAHASAN}

Perkembangan merupakan hasil belajar mengartikan bahwa perkembangan diperoleh melalui usaha, dukungan, latihan dan sumber daya manusia menjadi salah satu faktor yang sangat penting dalam perkembangan ekstrakurikuler. Penulis telah melakukan penelitian perkembangan ekstrakurikuler pencak silat SMA Negeri Kabupaten Lebong, dari hasil analisis bahwa perkembangan ekstrakurikuler pencak silat SMA Negeri Kabupaten Lebong masih kurang, dimana minat siswa nya kurang dalam mengikuti ekstrakurikuler pencak silat.

Ekstarkurikuler merupakan kegiatan pendidikan di luar jam pelajaran yang ditunjukkan untuk membantu perkembangan peserta didik, sesuai dengan kebutuhan, potensi, bakat dan minat mereka melalui kegiatan yang secara khusus diselenggarakan oleh pendidik atau tenaga kependidikan yang berkemampuan dan berkewenangan disekolah. Dalam Nurcahyo (2013:102) menjelaskan bahwa tujuan dalam ektrakurikuler olahraga yaitu untuk mengembangkan ekstrakurikuler dan minat siswa menuju tercapainya prestasi olahraga.

Pencak silat merupakan suatu beladiri yang diwariskan oleh nenek moyang sebagai budaya bangsa indonesia sehingga perlu dilestarikan, dibina dan dikembangkan. Menurut Johansyah Lubis dalam Maulana (2019: 33) dasar gerak pecak silat yaitu suatu gerak terencana, terarah, terkoordinasi dan terkendali yang mempunyai empat aspek bagian satu kesatuan, ialah aspek mental spiritual, aspek bela diri, aspek olahraga dan aspek seni budaya. Dengan demikian pencak silat merupakan cabang olahraga yang cukup lengkap untuk mempelajari karena memiliki empat aspek yang merupakan satu kesatuan dan tidak dapat di pisahpisahkan.

Banyak faktor- faktor yang mengakibatkan kurang berkembangnya pencak silat siswa SMA Negeri Kabupaten Lebong, minat siswa untuk mengikuti ekstrakurikuler pencak silat masih kurang,sarana prasarananya terbatas masih banyak pelatih belum memiliki sertifikat, kurang adanya dukungan dari sekolah sehingga mengakibatkan prestasi siswa tidak meningkat. Untuk meningkat perkembangan ekstrakurikuler perlu adanya sarana prasarana yang menjadi salah satu unsur penunjang keberhasilan olahraga dan membutuhkan sarana dan prasarana yang digunakan dalam penunjang tercapainya suatu keberhasilan dalam olahraga. Menurut Suryono dan Bagun Sri Hutomo (2016: 24) sarana merupakan suatu alat yang sangat penting dalam memberikan motivasi anak didik untuk bergerak aktif, sehingga siswa sanggup melakukan aktivitas dengan sesungguhnya dan akhirnya tujuan aktivitas dapat tercapai.

Hasil wawancara pembina ekstrakurikuler pencak silat SMA Negeri Kabupaten lebong, bahwa masih beberapa sekolah yang belum memiliki dukungan dari sekolah, masih kurangnya minat siswa untuk mengikuti ekstrakurikuler pencak silat, sekolah selalu bekerja sama dengan DISPORA dan KONI setiap siswa berprestasi selalu disampaikan ke DISPORA sehingga siswa mendapatkan penghargaan dari DISPORA.Peran pelatih sangat penting dalam kegiatan olahraga, adapun peran peran pelatih diantara lain: 1).pelatih akan menjadi instruktur penilai, 2)pelatih sebagai pembimbing dilapangan, 3) pelatih sebagai penasehat baik itu dilapangan maupun diluar lapangan, 4) pelatih sebagai motivator yang selalu 
memberikan dukungan kepada anak didikya.

Untuk mencapai sebuah prestasi perlu adanya intensitas latihan yang lebih tinggi, latihan merupakan rumusan segala daya dan upaya untuk meningkatkan secara menyeluruh kondisi fisik dengan proses yang sistematis dan berulang-ulang dengan kian hari kian bertambah jumlah beban latihan, waktu dan intensitasnya seorang melakukan latihan di karenakan merupakan suatu bentuk upaya untuk mencapai suatu tujuan. Untuk meningkatkan prestasi perlu adanya latihan yang lebih serius, dalam seminggu bisa melakukan 5 kali latihan sehingga bisa dapat meningkatkan prestassoKemudian hasil wawancara pelatih ekstrakurikuler pencak silat SMA Negeri Lebong, ada beberapa pelatih yang belum memiliki sertifikat, beberapa sekolah masih belum menyusun program latihan yang benar, program latihan seangat penting dalam mencapai sebuah prestasi, kurang disiplinnya siswa waktu latihan, pengalaman pelatih masih kurang dalam melatih.

Menurut Ihtiarini (2017:117) latihan yaitu serangkaian aktifitas fisik yang terstruktur, sistematis, yang dilakukan secara berulang-ulang.

\section{PENUTUP}

\section{Simpulan}

Berdasarkan data yang diperoleh pada perkembangan ekstrakurikuler pencak silat SMA Negeri di Kabupaten Lebong, dapat disimpulkan bahwa sumber daya manusia ekstrakurikuler pencak silat siswa SMA Negeri Kabupaten Lebong $27 \%$ kategori kurang, sarana prasana $24 \%$ kategori kurang, pengelolaan pendanaan $33 \%$ kategori kurang, metode dan program latihan 23\% kategori kurang. Bahwa perkembangan ekstrakurikuler pecak silat siswa SMA Negeri Kabupaten Lebong masih kurang. Terdapat beberapa faktor yang mempengaruhi dalam perkembangan ekstrakurikuler pencak silat SMA Negeri Kabupaten Lebong seperti kurangnya dukungan dari sekolah, dan kurang disiplin dalam melaksanakan latihan. Untuk mencapai sebuah prestasi perlunya dukungan dari keluarga, teman, masyarakat, dan motivasi menjadi modal dasar dalam meraih prestasi di setiap pertandingan.

\section{Saran}

Ada beberapa saran yang harus disampaikan sehubungan dengan penelitian ini, antara lainnya:

1. Agar lebih mengembangkan penelitian lebih dalam lagi tentang perkembangan ekstrakurikuler pencak silat siswa SMA Negeri Kabupaten Lebong.

2. Agar melakukan penelitian tentang perkembangan ekstrakurikuler pencak silat siswa SMA Negeri Kabupaten Lebong dengan metode lain.

3. Untuk penelitian selanjutnya diharapkan dapat menggambarkan korelasi positif untuk perkembangan ekstrakuriker pencak silat siswa SMA Negeri Kabupaten Lebong.

\section{DAFTAR PUSTAKA}

Alfarizi, Rizky (2018) Pengaruh Latihan Audio Dengan Langsung Terhadap Penguasaan Gerak Pencak Silat Kategori Tunggal. Skripsi. Yogyakarta: Universitas Negeri Yogyakarta.

Arikunto, Suharsimi (2006) Prosedur Penelitian Pendekatan Praktik. Jakarta

Damayanti, Anisa (2017) Kontribusi Power Otot Tungkai dan Kelincahan Terhadap Kemampuan Tendangan Sabit Pada Atlet Pencak Silat Satria Sejati Bandar Lampung [Skripsi].Lampung: Universitas Lampung. 
Hidayati, Nurul (2017) Upaya Institusi Dalam Menanggulangi Pengemis Anak Di Kota Banda Aceh.FISIP, Volume 2, Nomor 2. Jurnal. Banda Aceh:Unsyiah

Ihtiarini, W Fajar (20170 Pengaruh Latihan Ladder Drills Two Feet Square Dan Icky Shuffle Terhadap Kecepatan Gerak. Ilmu Keolahragaan, Volume 07, Nomor 3. Jurnal. Surabaya: Universitas Negeri Surabaya

Kalil, Buyung (2019) Pemetaan Prestasi Perguruan Pencak Silat Remaja Kabupaten Kaur. Skripsi. Bengkulu: Universitas Bengkulu

Lubis, Johanes dan Wardoyo, Hendro. (2015) Pencak Silat. Jakarta.

Marlianto, F., \& Yarmani, Y. (2018). Analisis Tendangan Sabit pada Perguruan Pencak Silat Tapak Suci di Kota Bengkulu. Kinestetik: Jurnal Ilmiah Pendidikan Jasmani, 2(2), 179-185.

Nurcahyo, Fathan. (2013) Pengelolaan dan Pengembangan Kegiatan Ekstrakurikuler Olahraga di SMA/MAN/SEDERAJAT Kabupaten Sleman. Pendidikan Jasmani, Voleme 9, NomOr 2. Jurnal. Yogyakarta: Universitas Negeri Yogyakarta.

Nasution, Fitri Haryani.dkk (2017) Buku Pintar Pencak Silat. Jakarta Timur

Pujianto dan Insanistyo (2018) Dasar-Dasar Penelitian Pendidikan Jasmani. Bengkulu: Fkip Universitas Bengkulu

Prabowo, Ganang (2018) Pengaruh Model Latihan Sirkuit Terhadap Peningkatan Biomotor Atlet Pencak Silat Usia 12-15 Tahun [Skripsi]. Yogyakarta: Universitas Negeri Yogyakarta.

Sulistiono. (2018) Anaslisi Manajemen Pembinaan Prestasi Pencak Silat di Kabupaten Tulang Bawang Provinsi Lampung. $\quad$ Skripsi. Yogyakarta: Universitas Negeri Yogyakarta.
Sugiyono. (2012). Metode Penelitian Kualitatif Dan R\&D. Bandung: Alfabeta,

Suryabrata, Sumadi (2014) Metodelogi Penelitian. Jakarta

Singgih,Angga (2017) Hubungan Antara Panjang Tungkai, Power Tungkai Dengan Kecepatan Tendangan Sabit Siswa Pada Ekstrakurikuler Pencak Silat di SMP Sunan Al-Ambiya Gondang Kecematan Taman Kabupaten Pemalang Yogyakarta:Universitas Negeri Yogyakarta.

Saputra, Yogi Rahmat (2019) Pengaruh Latihan Imagery Terhadap Tingkat Ketetapan Waktu Pencak Silat Kategori Tunggal [Skripsi]. Yogyakarta: Universitas Negeri Yogyakarta.

Sandria,Redi (2018) Perkembangan Ekstrakurikuler Sepak Takraw Ditingkat Smp Kabupaten Lebong [Skripsi]. Bengkulu: Universitas Bengkulu

Setiawan. H.B. (2012) Pengembangan Modul Pembelajaran Pencak Silat Sebagai Sumber Belajar Bagi Siswa Sekolah Menengah Atas [Skripsi]. Yogyakarta: Universitas Negeri Yogyakarta.

Wibowo,Kristianto.dkk(2017) Evaluasi Pembinaan Prestasi Olahraga Basket di Kabupaten Magetan. Media Ilmu Keolahragaan Indonesia, Volume 7,Nomor 1. Jurnal.Surakarta: Universitas Sebelas Maret.

Wardani, G. K.(2017) Pembinaan Prestasi Atlet Pencak Silat Dewasa di Kabupaten Klaten [Skripsi]. Yogyakarta: Universitas Negeri Yogyakarta.

Yanti,Noor.dkk. (2016). Peleksanaan Kegiatan Ekstrakurikuler Dalam Rangka Pengembangan Nilai-Nilai Karakter Siswa Untuk Menjadi Warga Negara Yang baikdi SMA Kopri Banjarmasin. Pendidikan Kewarganegaraan, Volume 6, Nomor 6.Jurnal. Lampung: Universitas Lampung. 